

\title{
IMPLEMENTATION OF ARTICLE 86 OF LAW NUMBER 13 OF 2003 CONCERNING MANPOWER,OCCUPATIONAL SAFETY AND HEALTH TOWARD OPERATOR OF GAS STATION NUMBER 21.381.09 AT RAWA MAKMUR OF BENGKULU CITY
}

By:

Sukma Jumiati, Candra Irawan, Ganefi

\begin{abstract}
Regarding labour protection, therefore the Law Number 13 of 2003 concerning Manpower,Article 86 Paragraph (1) Letter a and Paragraph (2) states that:"Every worker/labourer has the right to receive protection on occupational safety and health". Then, the researchers will discuss the implementation of article 86 of law number 13 of 2003 concerning Manpower, occupational safety and health toward an operator of the gas station number 21.381.09 at RawaMakmurof Bengkulu City. The aim of this research was to know the implementation ofarticle 86 of Law Number 13 of 2003 concerning Manpower toward the operator of gas station number 21.381.09 atRawaMakmurof Bengkulu City. This research was an empirical study of qualitative research. The data sources used were secondary and primary data sources. In collecting the data, the researcher used interview, observation and documentation. After doing research, it can be concluded the following: Legal Protection at the gas stationare done by using Security Administration Body for Employment (BPJS Ketenagakerjaan) and Healthcare Security (BPJS Kesehatan), and conducted directly protection by the company by providing sweetened condensed milk as a neutralizing immune system, protective footwear shoes, and fire extinguishers as firefighters.
\end{abstract}

Keywords: Implementation, Gas Stations, Operator, Manpower Offices 


\section{A. INTRODUCTION}

\section{Research Background}

The existence of a

Limited Liability Company, or better known as PT Persero obtain a comprehensive legal basis when the government issued the Law Number 19 of 2003 on State-Owned Entities(UUBUMN). In this Law, it was that mentioned State Owned Entity (SOE) consists of a Public Enterprises(Perum) and the Limited Liability Companies. The purpose and objective of the establishment of companies

Perseroaan confirmed in the SOE Act namely:

a. Provide high-quality goods/servicesandstrong competitive power

b. Make a profit in order to increase the company value.

Furthermore, in the explanation of this article, Persero as one of the national economic actors is required to be able to fulfil market demand through high-quality goods and services with strong competitiveness in the domestic and international markets. Therefore, it can increase profits and the value of Persero that will provide optimum benefits for the parties involved. ${ }^{1}$ Indonesia is a developing country, which of course, economic development also still requires an increase in the economic system that applies to Indonesia. The existence of the national economy is determined by a businessman. ${ }^{2}$ One of the drivers of the economy is labourers. Since this country was founded, the Indonesian people have realized that work is a fundamental requirement of citizens as stipulated in the Article 27 paragraph (2) of the Constitution of 1945 which states:

"Every citizen shall have the right to work and to earn a humane livelihood".

Affirmation of the Article above is part of an effort to achieve national goals, therefore the state requires supporting facilities, both in the form of human

\footnotetext{
${ }^{1}$ SentosaSembiring, Hukum Perusahaan Tentang Perseroan Terbatas, CV. NuansaAulia, Bandung, 2013, p.150-152

${ }^{2}$ Ahmadi Miru, SutrarmanYodo, Hukum Perlindungan Konsumen, PT RajaGrafindoPersada, Jakarta, 2007, Pg.1
} 
resources and objects in the form of objects because the state cannot do it alone. ${ }^{3}$

Therefore it requires workers or employees to achieve these objectives.

Worker/labourerdivide

d into several types of female worker/labourer, child worker/labourerand foreign worker/labourer.

Worker/labourerto do the job protected by the law governing the rights and obligations of workers /labourers, as well as rights and obligations of the employer. When exercising the rights and obligations of each good worker or workers and employers must comply with the regulations applicable Legislation.

\section{Problems in the} manpower itself are still so much which arise whether

${ }^{3}$ Sri Hartati, SetiajengKadarsih, TediSudrajat, HukumKepegawaian di Indonesia, SinarGrafika, Jakarta, 2014, p.5 caused by workers/labourers as well as those caused by the businessman. This is caused by the lack of rules or lack of application of the rules committed by businessman or workers. One of the problems that occur in the manpowerwas on the safety and health of workers/labourers.

Health and Safety (K3) is a program created for the workers/labourers and businessman in order to prevent the emergence of accidents and illness due to working relationships within the work environment by identifying things that could potentially cause accidents and diseases as a result of the employment relationship, and anticipatory action if there is such a thing. Workprotection can be done either by providing compensation, guidance and with the increasing recognition 
of human rights, economic social and physical protection through the norms prevailing in the company. ${ }^{4}$

Regarding the protection of labour, Act No. 13 of 2003 on Labor Article 86

Paragraph (1) Letter a and Paragraph (2) states that:

"Every worker/ labourer has the right to receive protection on occupational safety and health". While in paragraph (2) it states "In order to protect the safety of workers/labourers and to realize optimal productivity, an occupational health and safety scheme shall be administered".

Therefore, it is very clear that the safety and health of workers/labourers are a paramount priority in the conduct of its work. Referred to paragraph (1) of the letter a, each worker/labourershas the right to the protection of health and safety. In order to obtain their rights which remain in a state of productivity to their survival goes well. The company is also benefited by their performance that remains

${ }^{4}$ ZaeniAsyhadi, Hukum Kerja: Hukum Ketenagakerjaan Bidang Hubungan Kerja, King GrafindoPersada, Jakarta, 2007, p.78 productive and satisfying by providing protection of their performance. Hence the need for the protection of workers/labourers.

Based on the writer's observation that the workers or operators at the gas station at Rawa Makmur of Bengkulu city, in carrying out its work are according to the writer are still lack of attention in maintaining the safety and health of its work, which is caused by air pollution. Air pollution can be classified into three categories; first is friction surface, the second is evaporation, and the third is burning. ${ }^{5}$ While the problems faced by the gas station workers at Rawa Makmur of Bengkulu city is the second issue that is evaporation caused by fuel vapours when filling the fuel and of motor vehicles and cars. Motor vehicle pollution in large cities increasingly felt. The burning of gasoline in motor

\footnotetext{
5 A. TresnaSastrawijaya, Pencemaran Lingkungan, Rineka PT Cipta, Jakarta, 2000, p.168
} 
vehicles is more than halfthe causes of air pollution. ${ }^{6}$

The impact of the pollution for example when filling station operator in carrying out his work did not use a mask or cover of mouth. Because the mask is one tool that can minimize the risk to the health of the operators of gas stations when doing the activity.

The results of interviews that wasthe writer interviewed to the operators of gas station 21.381.09 at RawaMakmurof Bengkulu, on the health they experienced while working, namely:

"There have been employees who experience pain caused by work such as respiratory pain, lungs, coughing, flu, stomach often hurts, frequent fever, easily tired of the body, some operators have acne, and the body going thin and some operators that havelong married do not have children and there are also those who long for having children." ${ }^{7}$

Based on the above description, problems regarding Occupational Safety and Health for employees in

${ }^{6}$ Op, cit, p. 170

${ }^{7}$ Results of Interviews with operators, gas station 21.381.09 at RawaMakmur of Bengkulu city, 20:20 p.m. dated on 18-14-2018 the various companies, then in the company of gas station 21.381.09 at RawaMakmur of BengkuluCityin practice still found many problems regarding labour safety and health. One of the problems that the writer view is about the safety and health of workers of the operator at gas station 21.381.09 at RawaMakmur of BengkuluCity.

Based on the background as described above, the writer interested in doing research with title "IMPLEMENTATION OF ARTICLE 86 OF LAW NUMBER 13 OF 2003 CONCERNING MANPOWER, OCCUPATIONAL SAFETY AND HEALTH TOWARD

OPERATOR OF GAS STATION NUMBER 21.381.09 AT RAWA MAKMUR OF BENGKULU CITY".

\section{Identification of Problems}

Based on the above background, the problem can be formulated as follows: How does the implementation of Article 86 of Law Number 13 of 2003 Concerning Manpower, Occupational Safety and Health toward Operator of Gas Station Number 21.381.09 at Rawa Makmur of Bengkulu City?

\section{B. Research Methods.}

1. Types of Research

This type of research is field research because, in addition to using a descriptive approach, this research 
also requires precision in the field. And also the type of research was an empirical legal research. Legal research is a process to find legal rules, legal principles and legal doctrines to answer the legal issues faced. $^{8}$

\section{Data source}

a. Primary data;

Primary data is the data that the writer obtainedfrom directly interview with one of the supervisors and several operators of Operator of Gas Station Number 21.381.09 at Rawa Makmur of Bengkulu City.

b. Secondary Data;

The secondary data source is the source of the data obtained from supporting data. Includes information obtained through the data documentation, books or literature that relevant to support the theory of the

${ }^{10}$ Peter Mahmud Marzuki, Penelitian Hukum, KencanaPrenada Media, Jakarta, 2005, p.35 research conducted. This data was obtained through library research or derived from:

1) Primary Law Materials; Primary Law Materials is research material sourced from library research obtained from legislation, include:

a) Legislation of 1945;

b) Law No. 13 of 2003 on Manpower;

c) Government

Regulation No. 50 of 2012 on the Implementation of Occupational Safety and Health Management System;

d) Minister of

Manpower

Regulation No. 8

of 2011 on personal 
protection

equipment.

2) Secondary

Legal

Materials are legal

materials that provide an

explanation of primary

legal materials such as

legal facts, expert

opinions, dictionaries, legal principles, internet, and legal textbooks. ${ }^{9}$

\section{Data Collection Method}

a. Observation

Observation is an observation technique that requires observations from a researcher both directly and indirectly to the object under study by using instruments in the form of research guidelines in the form of observation sheets. ${ }^{10}$

b. Interview;

The interview is the process of obtaining information for the purpose of research by way of question and answers while

${ }^{9}$ SoerjonoSoekanto, Sri Mamudji, Penelitian Hukum Normatif, Eagle Press, Jakarta, 2012, Pg.33

${ }^{10}$ SumadiSuryabrata, MetodologiPenelitian, Eagle Press, Jakarta, 2012, p.38 meeting face to face between researchers and people interviewed. ${ }^{11}$ The interview is a technique of collecting data by way of verbal question and answer which is done intensively and deeply.

c. Documentation;

Documentation is a technique of collecting data by using documents as data sources. Documentation used as sources of information include documents and provides many advantages to the researcher.

\section{d. Literature Review}

Literature Review is a series of activities written by the writer with the intention of obtaining secondary data by reading, taking notes, and quoting from various literature, mass media books and other information related to research.By using the field observation guide carried out on

\footnotetext{
${ }^{11}$ A.Chaeder Al-Wasilah, Dasar-Dasar Merancang dan Melakukan Penelitian Kualitatif, Pustaka Jaya, Jakarta, in 2006, p.154
} 
the object of research, namely

Gas Station Number 21.381.09 at

Rawa Makmur of Bengkulu City.

\section{Data analysis}

Research data has been collected fully analyzed qualitatively. ${ }^{12}$ The analysis of the research carried out is qualitative analysis, namely data based on the description of the sentence or data not analyzed using statistics or mathematics or the like, namely what the respondent stated in writing or real behaviour that was studied and studied as something intact. ${ }^{13}$ Analysis canbe formulated as a systematic process of decomposition and consistent with certain symptoms. ${ }^{14}$

\section{RESULTS AND DISCUSSION}

Implementation of Article 86 of Law Number 13 of 2003 concerning Manpower, Occupational Safety and Health toward the operator of the gas station number 21.381.09 at Rawa Makmur of Bengkulu City. Here is a form of protection given by as station number 21.381 .09 at Rawa Makmur of Bengkulu City, the description as follows:

\section{Safety Protection}

\section{a. BPJS Ketenagakerjaan}

$$
\begin{aligned}
& \text { BPJS Ketenagakerjaan } \\
& \text { provides protection for }
\end{aligned}
$$
workers through 4 programs, among others:
1) Work Accident Security $(J K K)$

2) Old Age Security (JHT)

3) Death Security (JKM)

4) Pension Security $(J P){ }^{15}$

\section{b. Direct Safety Protection from $S P B U$}

${ }^{12}$ BurhanBungin, Metodologi Penelitian, PT RajaGrafindoPersada, Depok, 2012, p.153-154

${ }^{13}$ SoerjonoSoekanto, Dasar-Dasar Merancang dan Melakukan Penelitian Kualitatif, University of Indonesia Press, Jakarta, 1990, p.32
In addition, the protection provided in the

\footnotetext{
${ }^{15}$ Interview with the Chief of the gas station number 21.381.09 at Rawa Makmur of Bengkulu City, 15- 09-2018, 11:00 a.m.
} 
form

of

BPJS

Ketenagakerjaan and BPJS

Kesehatan by the company

also provides protection

directly in the field when

working. Safety protection

provided directly to the

operators of the gas station

number 21.381.09 at Rawa

Makmur of Bengkulu City;

1) Given safety (protective footwear shoes).

2) Provided $A P A R$ (fire extinguisher).

3) Doing SOP (Standard Operating Procedure) for each job.

2. Health Protection From SPBU.

a. BPJS Kesehatan

BPJS Kesehatan provides protection for workers through the program includes:

1) Sick

2) Operation

3) Traffic accident

4) Cancer and diseases are concerned with health and others.

\section{b. Direct Health Protection from}

Occupational health protection that provided directly for theoperators of gas station number 21.381.09 at Rawa Makmur of Bengkulu City are;

1) Provide sweetened condensed milk (extra pudding)

2) Providing medicine or $P 3 K$ box.

3. Efforts made by the company in implementing occupational safety and health protection for the operator of gas station number 21.381.09 at Rawa Makmur of Bengkulu City.

a. Improving socialization on the protection of occupational safety and health by gas stations.

b. Provision of Protective Equipment.

c. Training for $S P B U$ operators (Occupational Health Safety and Environmental Protection).

4. Inhibiting Factors in Implementation legal protection for occupational 
safety and health for operators

of the gas station number

21.381.09 at Rawa Makmur of

\section{Bengkulu City.}

a. The presence motto $3 \mathrm{~S}$ (Smiles, greetings, regards) from State Oil and Natural Gas Mining Company (Pertamina).

b. The lack of comprehensive knowledge of workers/operators.

c. Lack of awareness of the workers/operators on occupational health and safety protection.

5. Legal protection toward occupational health and safety toward operators of gas station number 21.381.09 at Rawa Makmur of Bengkulu Cityhas been implemented properly by the company through the program of BPJS Ketenagakerjaan and BPJS Kesehatan, but still not maximal, it is seen by the lack of implementation of the rules on occupational safety and health protection undertaken by the company for workers/operators gas station number 21.381.09 at Rawa Makmur of Bengkulu Cityrelated to the self-closing personal protective equipment on breathing apparatus.

\section{CLOSING}

\section{Conclusion}

Based on studies that have been done by the writer,itcan be concluded the following matters: The implementation of Article 86 of Law Number 13 of 2003 concerning Manpower toward the operator of the gas station number $21.381 .09 \quad$ atRawa Makmur of Bengkulu Cityis company has granted rights to employees operators in accordance with the provisions of Manpower Legislations in Indonesia. Occupational health and safety rights provided are in the form of BPJS Ketenagakerjaanand 
BPJSKesehatan then added by providing sweetened condensed milk as a neutralizing the body due to the impact of working to breathe $B B M$ steam. As well as personal protective equipment in the form of protective footwear shoes and fire extinguisher $(A P A R)$ as a fire alert).

\section{Suggestion}

As input from the writer regarding the implementation of Article 86 of Law Number 13 of 2003 concerning Manpower toward the operator of the gas station number 21.381.09 of Rawa Makmur Bengkulu City, namely: the company of gas station should provide protection for the operators to use mouth and respiratory protective masks. Then give a socialization in the form of blood checks for every few months for the operator to find out the health condition of the operator.

\section{REFERENCES}

A.Chaeder Al-Wasilah, Dasar-dasar Merancang dan Melakukan Penelitian Kualitatif, Pustaka Jaya, Jakarta, 2006

\section{Burhan Bungin, Metodologi Penelitian Kualitatif, PT RajaGrafindo Persada, Depok, 2012}

Peter Mahmud Marzuki, Penelitian Hukum, Kencana Prenada Media, Jakarta, 2005

SoerjonoSoekanto, KesadaranHukum Dan KepatuhanHukum, Rajawali, Jakarta,1982

Soerjono Soekanto, Sri Mamudji, Penelitian Hukum Normatif, Rajawali Pers, Jakarta, 2012

Soedjono Dirdjosisworo, Pengantar Ilmu Hukum, Jakarta: PT, Raja Grafindo Persada, 2012

Soerjono Soekanto, Pengantar Penelitian Hukum, Universitas Indonesia Press, Jakarta, 1990

Sumadi Suryabrata, Metodologi Penelitian, Rajawali Pers, Jakarta, 2012

Zaeni Asyhadie, Aspek-aspek Hukum Jaminan Sosial Tenaga Kerja di Indonesia, PT RajaGrafindo Persada, Jakarta, 2008 